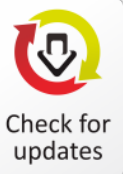

updates
Article Type: Research Paper

\section{Model for Calculating Cost of Laundry Services by Considering Environmental Impacts and Costs}

\author{
Elsje Kosasih ${ }^{1 *}$, Atty Yuniawati $^{1}$, Verawati Suryaputra ${ }^{1}$, \\ Amelia Limijaya ${ }^{1}$
}

\begin{abstract}
This research aims at developing a model for calculating cost of laundry services performed by small-scale laundry businesses which incorporate environmental impact and costs into the model. The activity-based costing method is used to assign indirect costs to the cost object. This research is a continuation of the previous research that we have conducted in several smallscale laundry businesses located in Bandung, West Java. Since environmental impacts and costs are considered, there will be changes in the resources and activity consumed, compared to the original model, which has not taken into account environmental factors. We identified several environmental costs, such as eco-detergent and plastic, government fines, loss of customers, and environmental costs borne by wider society. In analyzing the environmental costs, EPA classification is used. The suggested model is still in the theoretical phase, as some environmental costs arising from laundry business activities are difficult to measure. Some recommendations to laundry businesses and government are provided.
\end{abstract}

KEYWORDS: activity-based costing; cost of services; environmental costs; environmental impact; laundry

\section{Introduction}

In big cities in Indonesia, more and more people are working so that there is not much time left to do house chores such as doing laundry. At the same time, those who are previously working as housemaids prefer to work as factory workers or as housemaids abroad. These two conditions create an opportunity to open small-scale laundry businesses. This laundry business targeted boarding houses, small-scale hotels, even residential houses by offering laundry services at a low price. In the last couple of years, small-scale laundry has flourished. This attracts more people to open the business, which, in turn, creating more competition among them. Therefore, cost information becomes crucial for them to win the competition. 
Kosasih, Yuniawati, Suryaputra, \& Limijaya

Model for Calculating Cost of Laundry Services by Considering Environmental Impacts and Costs

Given the nature of the business where competition is intense whereas there are not many differences in services provided by each company, small-scale laundry businesses use market-based pricing method and do not calculate service (product) cost. Product cost information enables companies to determine product profitability, thus enables them to make appropriate product-related decisions, to make reliable planning and control, and to increase efficiency.

Laundry processes involve several stages that utilize a different type of resources at a different rate of consumption. Most of the costs involved are indirect cost with laundry services as the cost object. Therefore, we decided to use activity-based costing system to develop the model of service cost calculation for the laundry business.

Laundry businesses generate positive and negative impacts on society. More than merely helping in handling house chores, their existence creates jobs for nearby society. However, they utilize huge amount of water in the process and produce a high level of wastewater from the process. The businesses frequently are not aware of the negative impacts they create to the environment. The water-related issue should not be considered lightly since the supply of clean water becomes scarce nowadays and becomes an issue in and of itself. Environmental impacts produce environmental costs. Thus, it is important for the companies in question to incorporate environmental costs in the calculation of product cost to have a more comprehensive product cost information.

To the best of authors' knowledge, there has not been any previous research on environmental management accounting (EMA) topic that is integrated into the cost of services calculation in the laundry business. For example, a research conducted by Gunarathne and Lee (2015) focused on the development and implementation of EMA in hotel businesses in Sri Lanka, similar to what Jankovic, Persic, and Gavranic (2011) did previously in the Croatian hospitality industry in which they reviewed the role of EMA in hotel management systems. Although these two studies did discuss EMA, they took hotel business as the scope; meanwhile, in this study, we choose laundry business. Having said that, there are exist several studies on the laundry business. However, the focus is not on incorporating environmental costs into the cost of services calculation. For instance, there is a study on laundering practices in Norway and the strategies recommended to help consumers shift to a more sustainable laundry habit (Laitala, Klepp, \& Boks 2012). Before that, the same researchers also conducted a study to see the availability of options, which can be utilized to change consumer habits in clothing maintenance to a more environmentally-friendly one, by considering the feasibility as well as the efficiency of the options (Laitala, Boks, \& Klepp 2011).

Meanwhile, Mir, \& Feitelson (2007) studied the environmental behavior in small service family firms, one of which is laundry business, in Jerusalem. Thus, previous research mentioned above either focused on the hospitality industry or behavioral aspect, and none discussed the inclusion of environmental aspect into cost calculation. Nevertheless, Ngwakwe (2009) highlighted the importance of incorporating environmental costs into product costs calculation, but did not discuss the detail to do 
Kosasih, Yuniawati, Suryaputra, \& Limijaya

Model for Calculating Cost of Laundry Services by Considering Environmental Impacts and Costs

so. Previously, Rogers and Kristof (2003) classified environmental costs into variable manufacturing overhead costs, whereas in this research, they can be categorized as direct and indirect costs. Kreuze and Newell (1994) explained that using activity-based costing $(A B C)$ system to allocate costs to the product could benefit a company to manage environmental costs efficiently. Thus, this research attempts to include environmental costs into product cost calculation by using the $A B C$ system.

We have researched to create a model of product cost calculation for small-scale laundry that incorporates environmental costs. Environmental impacts of small-scale laundry businesses were identified along with their environmental costs. To the best of authors' knowledge, this type of study has never been undertaken previously by other researchers.

This research aims to:

1) Identifying direct and indirect costs of small-scale laundry business with laundry services as the cost object, including environmental cost created by the business.

2) Assigning direct and indirect costs identified using activity-based costing system to laundry services.

3) Creating a model of laundry services cost calculation for a small-scale laundry business.

4) Contributing to the local regulator in issuing business permits to laundry businesses by considering their environmental impacts.

Thus, this research contributes to the inclusion of environmental impact and costs of doing laundry business, which is usually not considered. By doing so, this study contributes to the growing literature of environmental management accounting as well as more established literature of full costing, specifically to include environmental costs in product costs calculation.

\section{Literature Review}

\section{Laundry Business}

Laundry business is included as a service organization. According to Onat, Anitsal, and Anitsal (2014, p. 155), laundry service is a kind of possession processing service. In possession processing service, tangible actions are performed on people's possessions, such as house remodeling, pet grooming, and dry cleaning. Described below are laundry business types and their development in Indonesia.

In an article at www.pewangilaundry.co.id, laundry can be defined as a place to wash and dry clothes, as well as it is done at the house, hotel, or special facility. Laundry businesses can be grouped into: 
Kosasih, Yuniawati, Suryaputra, \& Limijaya

Model for Calculating Cost of Laundry Services by Considering Environmental Impacts and Costs

1) Commercial Laundry: operates in the private sector, serves laundry to hotels, restaurants, delivery, and transportation, domestic or public, nursing home/hospital/clinic.

2) Industrial Laundry: operates in the private sector, serves laundry to the manufacturer and other sources of industry such as office, supermarket, retail stores, and service center.

3) Hospital Laundry: serves laundry to hospital, clinic, dental care, day care, nursing home, mental health institution, general public health service center.

4) Institutional Laundry operates in areas such as system institution, jail, and mental health institution.

5) Laundry on-premises: generally, operates at hotel, industry, nursing home, private hospital, industry, and the service is used by internal.

6) Coin Laundry: the laundry activated by coins, usually run by an individual or small agency, such as an apartment, and mall.

\section{The Development of Laundry Industry in Indonesia}

The laundry industry in Indonesia has grown quite rapidly and has good prospects in the future, as stated by Wasono Raharjo as Ketua Umum Asosiasi Pengusaha Laundry Indonesia (Chairman of Indonesian Laundry Entrepreneurs Association) in "Expo Clean and Laundry 2014" event and quoted by www.beritasatu.com. Even, it was estimated that the business turnover could reach 60 trillion rupiahs per year as said by H.M. Shiddiq, who is Ketua Asosiasi Perusahaan Klining Servis Indonesia (Chairman of Indonesian Cleaning Service Company Association) and quoted by SWA Magazine. The fast-growing of this business has positive impacts, such as increasing labor demand by this industry, which could increase community income and tax potential, thus can increase Government income.

Specifically, small size laundry businesses, as the focus of this research, are increasingly emerging and developing because of these factors:

1) Increasing activity and mobility of the community.

Nowadays, people are busier and highly mobile. Therefore, the time that was previously allocated to do household affairs, including washing and ironing clothes, is now used for other activities that are more productive. Then, many people use laundry business to wash and iron their clothes.

2) Growing in practical culture in society.

Washing, drying, and ironing activities are presumed time-consuming, so it is more practical to use laundry service than do those themselves.

3) The development of types of clothing material.

With the development of types of clothing materials and models, washing and care instruction become complicated and hard to do. Therefore, many people switch to laundry service to preserve their clothes.

4) Affordable prices.

Laundry services offer many types of service with affordable prices, so there is a high demand from the community for laundry services. 
Kosasih, Yuniawati, Suryaputra, \& Limijaya

Model for Calculating Cost of Laundry Services by Considering Environmental Impacts and Costs

In order to sustain and even grow in this competitive environment, the company needs to take some actions, such as controlling costs so that they can operate efficiently and maintaining quality so that they have a good relationship with customers.

\section{Definition and Classification of Cost}

According to Datar and Rajan (2018, p. 49), "a cost is a resource sacrificed or forgone to achieve a specific objective. A cost (such as the cost of labor or advertising) is usually measured as the monetary amount that must be paid to acquire goods or services". In line with Datar and Rajan, Guan, Don, and Maryanne said that (2009, p. 24) "Cost is the cash, or noncash asset sacrificed for goods and services that are expected to bring a current or future benefit to the organization". In this research, the calculation of service cost is done with Activity Based Costing System. Before calculating service cost, we should classify costs into direct or indirect costs. The definition put forward by Hilton and Platt (2015, p. 51) is as follows:

"Direct cost of a cost object is a cost that can be traced to a particular cost object.... Indirect cost of a cost object is a cost that cannot be traced to a particular cost object."

The cost object, according to Datar and Rajan $(2018$, p.49) is anything for which a cost measurement is desired. So, the classification of costs depends on the cost object. Besides that, other factors that influence the classification are the materiality of cost in question, availability of information-gathering technology, and design of operation (Datar\&Rajan 2018, p.49).

\section{Activity-Based-Costing System (ABC)}

Activity Based Costing System is a costing system in which multiple overhead cost pools are allocated using bases that include one or more non-volume-related factors (Carter, Usry, \& Hammer, 2002, p. 370). The calculation of cost using ABC will give benefit to the company because this system assigns indirect cost more accurately, as stated by Kaplan and Atkinson (1998, p. 97) "Activity-Based-Costing developed to provide more accurate ways of assigning the cost of indirect and support resources to activities, business processes, products, services, and customers". The calculation of cost using ABC System could be described as portrayed in the Figure 1. It can be seen that the process of assigning indirect cost is done in two stages, assigning the cost of a resource to activity and assigning cost of activity to cost object.

The process of assigning cost in ABC, according to Datar and Rajan (2018, p. 184-188), consists of 7 stages:

1) Identify the products that are the chosen cost objects.

2) Identify the direct cost of the products.

3) Select the activities and cost-allocation based to use for allocating indirect costs to the products. 
4) Identify the indirect costs associated with each cost-allocation base.

5) Compute the rate per unit of each cost-allocation base.

6) Compute the indirect costs allocated to the products.

Compute the total cost of the products by adding all direct and indirect costs assigned to the products.

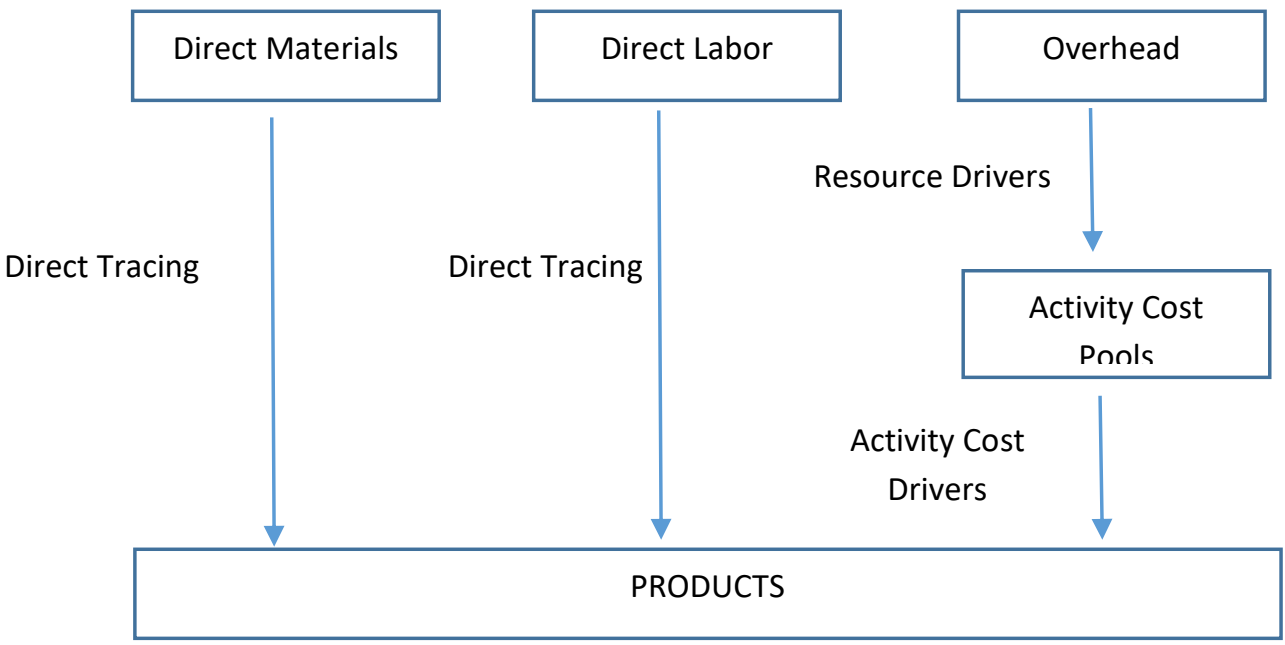

Figure 1 Activity-Based Costing System Diagram

Source Guan et al. (2009, p. 96)

The steps of assigning cost with $A B C$ according to Garrison, Noreen, and Brewer (2015, p. 314) are similar to Datar and Rajan's, which are: a) Define activities, activity cost pools, and activity measures b) Assign overhead costs to activity cost pools c) Calculate activity rates d) Assign overhead costs to cost objects using the activity rates and activities measures e) Prepare management reports. Datar and Rajan (2018) clearly show that the process of assigning cost begins with defining cost objects and identification of direct and indirect costs, while Garrison et al. (2015) suggests the stages of assigning indirect cost explicitly, especially related to assigning resources cost to activities.

Although $A B C$ system gives an advantage in assigning indirect costs more accurately, not all organization could be benefited. Below are the characteristics of a company that will be benefited when applying ABC (Datar \& Rajan 2018, p. 190):

1) Significant amounts of indirect costs are allocated using only one or two cost pools.

2) All or most indirect costs are identified as output unit-level costs (few indirect costs are described as batch-level costs, product-sustaining costs, or facilitysustaining costs). 
Kosasih, Yuniawati, Suryaputra, \& Limijaya

Model for Calculating Cost of Laundry Services by Considering Environmental Impacts and Costs

3) Products make diverse demands on resources because of the difference in volume, process steps, batch size, or complexity.

4) Products that a company is well-suited to make and sell show small profits; whereas products that a company is less suited to make and sell show large profits.

5) Operation staff has a substantial disagreement with the reported costs of manufacturing and marketing products and services.

In order to apply ABC well, we should notice these four factors (Chea, 2011):

1) The drive to change should be from the organization itself.

2) The adoption of $A B C$ should be believed by the operation manager before submitted to the top management.

3) All employees should feel to have the $A B C$ and responsible for the application.

4) The reasons to use $A B C$ should be communicated to all employees.

\section{Life Cycle Costing}

In laundry businesses, there are a lot of environmental impacts that do not appear in the time of production or in time of delivering service to customers. Instead, those impacts are recognized after those processes. Therefore, it is important to calculate the long term environment cost and effect. According to Kreuze and Newell (1994) in their article, "Life-cycle costing measures the entire $100 \%$ of these costs (full costs over the product's/system's/operation's life cycle), not just the costs incurred during production, and responsibility for environmental impacts has extended product costs well beyond the life cycle of the product. Responsibility for hazardous waste, for example, lasts forever. Therefore, all costs are discounted to the present to facilitate comparison with competing products". The definition of life cycle costing according to Datar and Rajan (2018) is: "Life-cycle costing tracks and accumulates business function costs across the entire value chain from a product's initial R\&D to its final customer service and support" (Datar and Rajan 2018, p. 560).

Based on the description above, in calculating the cost of laundry service, we should combine life cycle costing with Activity Based Costing System. According to Kreuze and Newell (1994), "The merging of life-cycle costing and ABC is not a revolutionary approach. Consideration of all costs, from the introduction phases to product maturity, can allow for the development of better design methods, production methodologies, marketing strategies, and disposal options. Environmental expenditures must be a major part of those considerations."

\section{Environmental Management Accounting}

$A B C$ system is part of management accounting. The increasing rate of environmental destructions coupled with higher awareness about the importance of the environment to sustainability drives further development in management accounting. Environmental Management Accounting (EMA) is a subset of management accounting that specifically 
Kosasih, Yuniawati, Suryaputra, \& Limijaya

Model for Calculating Cost of Laundry Services by Considering Environmental Impacts and Costs

deals with environment. EMA provides management with information, financial and nonfinancial, regarding environmental impacts of company activities so that this information is considered in decision making. Langfield-Smith, Thorne, and Hilton (2009) differentiate EMA into two categories:

1) Financial EMA deals with the calculation of environmental costs, which are costs incurred to prevent, monitor and report environmental impacts and the cost of failing to comply with environmental regulations

2) Physical EMA deals with techniques that focus on supplying information to management that accounts for the organization's impact on the natural environment

\section{Environmental Costs}

Environmental costs, according to Guan, et al. (2009), are costs that are incurred because poor environmental quality exists or may exist $(2009$, p. 512). There are many classifications of environmental costs, as will be discussed below. Collier (2012) classifies environmental costs based on the purpose of costs, whether they are incurred to prevent waste or to handle the resulted waste from a process. They are: (1) Costs of environmental protection (before), and (2) Costs of remedying problems caused during the production process (after). Rimer (2000) categorized environmental costs into three groups in term of their connection with environment-related regulations, as follows:

1) Compliance costs are associated with equipment or activities which are directly required for environmental reasons, and either the activity or equipment would not be used if regulations were not the driver

2) Preventive costs are associated with an activity or equipment which will prevent or minimize the applicability of a particular regulation

3) Green costs are an activity or piece of equipment used to voluntarily reduce the company impact on the environment and are not required specifically by regulation.

Environmental Protection Agency, as cited by Langfield-Smith et al. (2009), gives a different classification of environmental costs. The classifications are:

1) Conventional costs

Direct costs associated with capital expenditures, raw materials, and other operating and maintenance costs

2) Hidden costs

Hidden regulatory costs from activities such as monitoring and reporting of environmental activities and emissions, cost of searching for environmentally responsible suppliers, and the ongoing cost of cleaning up contaminated land

3) Contingent costs

Contingent liabilities arising from failure to clean up contaminated sites, and fines and penalties for non-compliance with regulations

4) Relationship and image costs 
Kosasih, Yuniawati, Suryaputra, \& Limijaya

Model for Calculating Cost of Laundry Services by Considering Environmental Impacts and Costs

Less tangible costs and benefits that relate to consumer perceptions and employee and community relations

5) Societal costs

Costs that organizations impose on others - the environment and society - for which they may not be held legally responsible and which cannot be compensated for in the legal system

\section{Methods for Environmental Costs Measurement}

Sigma guidelines (2003, p. 49) explained several methods to measure environmental costs. Most of them quantify the monetary value of benefits or costs obtained from the environment from the stakeholders' point of view. Environmental costs are calculated based on Willingness to Pay (WTP), which is the amount of money a person is willing to pay to obtain environmental benefits, or Willingness to Accept (WTA), which is a reduction in payment for a person's willingness to suffer environmental destructions. For example, house $A$, located in an area with clean air and water, is on the market for IDR 3.000.000.000,-. While house B, similar to house A, but located in area near a landfill, is on the market for IDR $250.000 .000,-$. A person who buys house A incurs IDR 50.000.000,- environmental costs using the WTP approach; pay more to obtain cleaner air and water. Another person who buys house B also incur IDR 50.000.000,environmental costs using WTA approach; pay less but suffering low-quality air and water. The methods are further categorized into demand-side methods and supply-side methods. Demand-side methods are:

1) Hedonic Pricing

This method uses information from a surrogate market to estimate the implicit value of an environmental good or service. For example, differential housing prices can be used to estimate how much extra people are willing to pay for residential property in areas free from traffic or industrial air pollution.

2) Travel Cost Method

This method uses a combination of surveys and surrogate markets to estimate the demand curve for an environmental resource. As its name implies, the travel cost method infers willingness to pay for environmental goods and services from the time and expense involved in traveling to them. Conventionally, the method is used to derive values for recreational sites.

3) Contingent Valuation Method

CVM elicits information on environmental preferences directly from the individual using surveys, questionnaires, or experimental techniques. CVM is based on hypothetical behavior inferred from surveys or experiments rather than on actual observed behavior. It has wide application but is the most unreliable of the methods as it is subject to several inherent biases.

Supply-side methods are:

1) Productivity Approach 
In this technique, environmental quality is viewed as a factor of production. Changes in environmental quality lead to changes in productivity and production costs, which in turn lead to changes in prices and output, which can be measured and observed. For example, improvements in soil conservation will feed through into changes in agricultural yields and prices. Hence, the costs of soil erosion can be evaluated using information obtained from agricultural markets.

2) Preventive Expenditure Method This approach has much intuitive appeal in that it is based on actual expenditure incurred to prevent, eradicate, or reduce adverse environmental effects.

3) Replacement Cost Method

This is an ex-post environmental valuation approach. In other words, it estimates replacement or restoration costs once environmental damage has taken place. Expenditures to neutralize soil and water acidity from agricultural run-off are examples of the costs incurred to restore damaged environmental assets to their original state.

Ecosystemvaluation.org explains methods to measure the economic value of the ecosystem in a monetary amounts, such as:

1) Market Price Method

Estimates economic values for ecosystem products or services that are bought and sold in commercial markets.

2) Productivity Method

Estimates economic values for ecosystem products or services that contribute to the production of commercially marketed goods

3) Hedonic Pricing Method

Estimates economic values for ecosystem or environmental services that directly affect market prices of some other good. Most commonly applied to variations in housing prices that reflect the value of local environmental attributes.

4) Travel Cost Method

Estimates economic values associated with ecosystems or sites that are used for recreation. Assumes that the value of a site is reflected in how much people are willing to pay to travel to visit the site.

5) Damage Cost Avoided, Replacement Cost, and Substitute Cost Methods

Estimate economic values based on costs of avoided damages resulting from lost ecosystem services, costs of replacing ecosystem services, or costs of providing substitute services.

6) Contingent Valuation Method

Estimates economic values for virtually any ecosystem or environmental service. The most widely used method for estimating non-use, or "passive use" values. Asks people to directly state their willingness to pay for specific environmental services, based on a hypothetical scenario.

7) Contingent Choice Method 
Kosasih, Yuniawati, Suryaputra, \& Limijaya

Model for Calculating Cost of Laundry Services by Considering Environmental Impacts and Costs

Estimates economic values for virtually any ecosystem or environmental service. Based on asking people to make tradeoffs among sets of the ecosystem or environmental services or characteristics. Does not directly ask for willingness to pay-this is inferred from tradeoffs that include cost as an attribute.

8) Benefit Transfer Method

Estimates economic values by transferring existing benefit estimates from studies already completed for another location or issue

In some cases, the monetary value of environmental degradation is still difficult to measure. In that case, it is advisable to rank each determinant factor and assess each project based on its qualification on every factor. Then, a project with the highest value will be selected. Examples of determinant factors are emission level, noise level, and water PH level.

\section{Environmental Impacts of Laundry Business}

Laundry business uses a huge amount of energy, especially water, and generates a significant amount of waste to the environment. An article in The Guardian (October 2014) revealed a result of a study in the UK that energy usage of each unit of washer and dryer has decreased due to technological improvement. However, the overall energy usage of laundry activities has increased since more households own washer and dryer, and they are doing these activities more frequently than before. These findings confirm that the approach to sustainability cannot be done partially. Instead, it should be done comprehensively and in an integrated way so that the overall effects on the environment are positive. One example to overcome this condition was done in Sweden by establishing a communal area for clothes drying in a residential area.

Putro (2014) researched Sleman regency, Depok District, to find out the impacts of small-scale laundry business on the environment, in term of groundwater usage and wastewater treatment. This research discovered that most laundry businesses used groundwater and only a small number owned sewage treatment plant. It is also discovered that harmful chemical in detergent encouraged the growth of eceng gondok (eichorniacrassipes) and other weeds, which would hinder the flow of the river. An article published in TribunYogya (2013) revealed further that wastewater from the laundry business would contaminate groundwater if not previously treated. Olivia Lewi Pramesti's research pointed out that laundry business produced waste containing a harmful chemical which lowered water quality, increased E-Coli content of the water, triggered health issues, and caused environmental destructions. Research by Asfawiand Yuantari (2014) in Pindrikan Kidul Village, Semarang uncovered several environmental impacts of small-scale laundry businesses. Most of the respondents in this research dumped waste water to the sewer without neutralizing it. As a result, wastewater with a high concentration of harmful chemical altered the composition of chemical in the ecosystem and disturbed the life in the ecosystem. Further, it disturbed the ecosystem's function as a natural purifier. 
Kosasih, Yuniawati, Suryaputra, \& Limijaya

Model for Calculating Cost of Laundry Services by Considering Environmental Impacts and Costs

\section{Mechanisms to Reduce Environmental Impacts of Laundry Business}

In general, people are aware of the negative impacts that the laundry business put into the environment. Therefore, some actions have already been done to deal with this issue. Based on the research done by I Made Elpera Yuda in Yogyakarta, local authority has required every laundry business to obtain nuisance permit ( $\mathrm{HO}$ - Hinder Ordonantie), which states that every laundry business 1 ) should use eco-friendly detergent to prevent environmental degradation, 2 ) is not allowed to dispose waste into city-governed sewer, and 3) has the facility to neutralize the waste. However, the implementation of these requirements has not been reinforced properly. Inspection is merely intended to ensure that every laundry business has the permit. As for ensuring the implementation, the authority relies on written complaints from the society in conducting an inspection and in taking appropriate actions. Based on his research, Satriyadi suggested the use of eceng gondok in wastewater disposal area to reduce the effects of harmful chemical contained in the wastewater. Eceng gondok has the ability to break waste into components that are less harmful to the environment.

An article http://bisnisukm.com discussed several ways to minimalize the negative impacts of laundry businesses. First, by using green (eco-friendly) detergent to reduce the harmful chemical in the wastewater. Next, by building a simple sewage treatment plant using pebbles, sand, and cotton fiber as a clarifier to purify wastewater from harmful chemicals. Another solution is by choosing a location that is far from the residential area. One example of green laundry practice is a laundry business run by Koperasi Desa Sukadanau (KDS), located in Kampung Jarakosta, Sukadanau Village, West Cikarang District, Bekasi Regency. This laundry business (Green Laundry) has its own simple sewage treatment plant, which is supported by the CSR program of Coca Cola Amatil. Wastewater that has been purified using the facility so far is utilized to water the plants and is proposed to be used in catfish cultivation.

An article in TribunYogya (2013) stated a solution proposed by Badan Lingkungan Hidup Yogyakarta to reduce environmental impacts by suggesting that every laundry business should have its own sewage treatment plant. Since this solution involves a large amount of investment, an alternative solution would be by requiring the business to cooperate with independent sewage water plant.

Another way to reduce the environmental impacts of laundry business is by making clear to the business about the magnitude of costs created by these impacts and how much of these costs are borne by the business - realizing how the impacts on the environment influence the financial performance of the business will motivate the business to take appropriate actions in reducing those impacts.

\section{Research Method}

This is qualitative research, based on a case study. A convenience sample of Micro and Small Business operated in the laundry industry in Bandung area were taken. The data 
were collected using observation, in-depth interview, and literature study. The research process is explained in the following paragraphs.

A preliminary study was performed by visiting several laundry businesses in Bandung and conducting interviews to know the calculation of the cost of laundry services and the impact of laundry businesses' activities on the environment. In this preliminary study, interviews were conducted to get an overview of business process, available documents, the calculation of the cost of laundry services already performed, assets required, data on costs incurred, and the calculation of profit/ loss as well as the selling price. At the end of this preliminary study, it was then decided which laundry businesses that would become the research units.

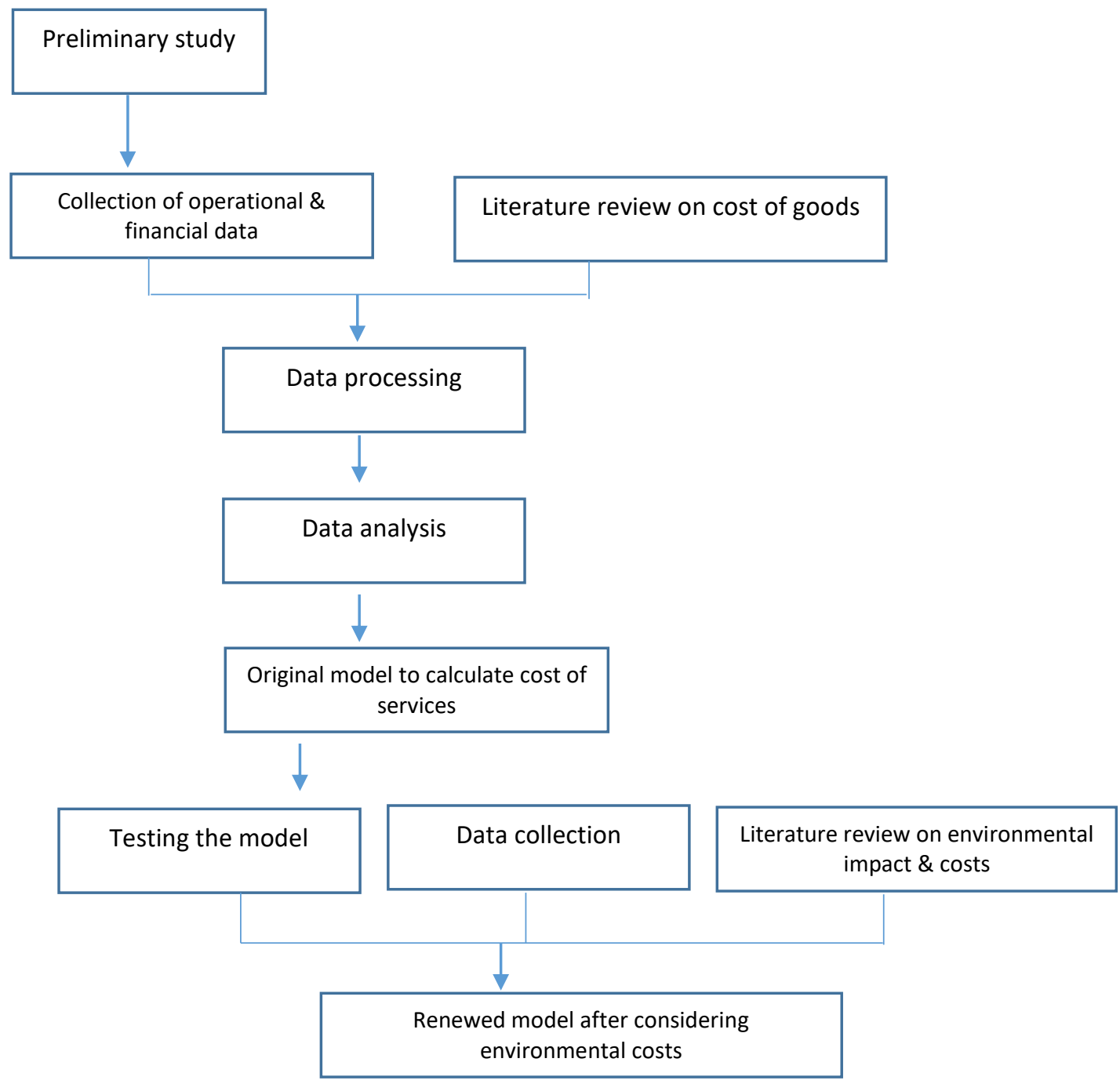

Figure 2 The Research Process 
Based on the result of the preliminary study, it was decided to use the interview as the method of data collection. Interviews were performed in a structured way in order to acquire in-depth and detailed data. Interviews were conducted to several laundry businesses who have appropriate data needed in this research. From this preliminary study, a literature review was performed to identify the most appropriate theory and concept to be applied to the laundry business in order to calculate the cost of laundry services. This literature review was done by reading textbooks and journals related to cost of services, laundry business, small and medium-sized business. After conducting this literature review, we then decided on the most appropriate method to calculate the cost of laundry services.

Data processing was done by choosing the data that will be used, classifying costs data based on activities, and constructing tables on costs and activities. Afterward, an analysis was performed to assign resource costs to activities as well as activity costs to cost object, i.e., laundry services. It is from this stage that the model for calculating the cost of laundry services was created.

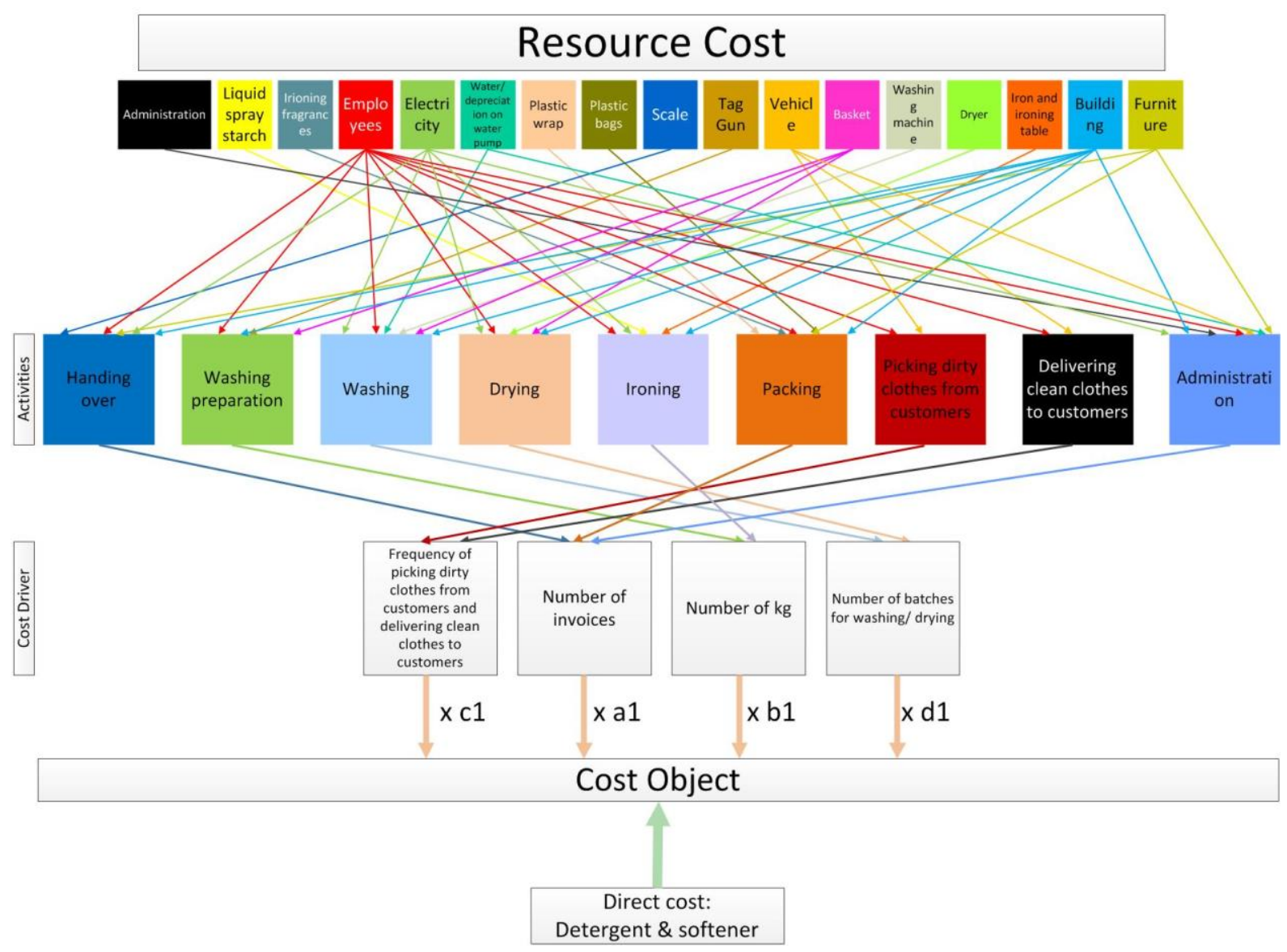

Figure 3 Chart of Cost Calculation Model for Laundry Company 
The model was then tested to several laundry business owners through a training program, in which the business owners tried to calculate the cost of laundry services based on the developed model. From this training program, input was gathered to make this model perfect, and thus become more applicable. Next, data and literature review on environmental impact and costs of laundry business were collected. Based on this, the model was then revised, to include environmental impact and costs of laundry businesses.

\section{Result and Discussion}

In the previous research (Kosasih, Yuniawati, Suryaputra, \& Limijaya, 2017), we have taken some samples of laundry business in Bandung area to get a clear picture of the characteristics of laundry business, types of service offered, activities done, and some data of the cost to support the design of a model to calculate the cost of services. Based on this information, we have designed a cost calculation model for the laundry business in accordance with the real activities done by the laundry company as shown in Figure 3.

Table 1 Resource Cost Driver to Allocate Resource Cost to Activities

\begin{tabular}{|c|c|c|c|}
\hline No & Type of Cost & Resource Cost Driver & Allocated to \\
\hline 1 & Cost of employees & Time (work hours) & $\begin{array}{l}\text { Picking dirty clothes from } \\
\text { customers, handing over, } \\
\text { washing preparation, } \\
\text { washing, drying, ironing, } \\
\text { packing, delivering clean } \\
\text { clothes to customers, } \\
\text { administration activities. }\end{array}$ \\
\hline 2 & Cost of vehicle & $\begin{array}{l}\text { Activity frequency, consisting } \\
\text { of picking dirty clothes, } \\
\text { delivering clean clothes, and } \\
\text { managing company } \\
\text { (administration) }\end{array}$ & $\begin{array}{l}\text { Picking dirty clothes, } \\
\text { delivering clean clothes, } \\
\text { administration activities. }\end{array}$ \\
\hline 3 & Cost of scale & - & Handing overactivity \\
\hline 4 & $\begin{array}{l}\text { Cost of furniture (except } \\
\text { ironing board) }\end{array}$ & $\begin{array}{l}\text { Time usage for handing over } \\
\text { and administration activities }\end{array}$ & $\begin{array}{l}\text { Handing over, packing, } \\
\text { administration activities. }\end{array}$ \\
\hline 5 & $\begin{array}{l}\text { Cost of washing } \\
\text { machine }\end{array}$ & - & Washing activity \\
\hline 6 & Cost of dryer & - & Drying activity \\
\hline 7 & Cost of tag gun & - & $\begin{array}{l}\text { Washing preparation } \\
\text { activity }\end{array}$ \\
\hline 8 & Cost of basket & $\begin{array}{l}\text { Number of batches for } \\
\text { washing and drying }\end{array}$ & $\begin{array}{l}\text { Washing preparation, } \\
\text { washing, drying activities }\end{array}$ \\
\hline 9 & $\begin{array}{l}\text { Cost of irons and ironing } \\
\text { board }\end{array}$ & - & Ironing activity \\
\hline 10 & Cost of building & $\begin{array}{l}\text { The size of the room. If one } \\
\text { room is used for several } \\
\text { activities, room usage time for } \\
\text { certain activities is used for its } \\
\text { allocation }\end{array}$ & $\begin{array}{l}\text { Handing over, washing } \\
\text { preparation, washing, } \\
\text { drying, ironing, packing, } \\
\text { administration activities }\end{array}$ \\
\hline
\end{tabular}


Kosasih, Yuniawati, Suryaputra, \& Limijaya

Model for Calculating Cost of Laundry Services by Considering Environmental Impacts and Costs

Table 1 Resource Cost Driver to Allocate Resource Cost to Activities (Continued)

\begin{tabular}{|c|c|c|c|}
\hline No & Type of Cost & Resource Cost Driver & Allocated to \\
\hline 11 & Cost of administration & - & Administration activity \\
\hline 12 & Cost of water usage & - & Washing activity \\
\hline 13 & $\begin{array}{l}\text { Material cost for liquid } \\
\text { spray starch }\end{array}$ & - & Ironing activity \\
\hline 14 & $\begin{array}{l}\text { Material cost for ironing } \\
\text { fragrances }\end{array}$ & - & Packing activity \\
\hline 15 & $\begin{array}{l}\text { Cost of plastic wrap and } \\
\text { plastic bags }\end{array}$ & - & Packing activity \\
\hline 16 & Cost of electricity & $\begin{array}{l}\text { Electrical power and time } \\
\text { (kwh) }\end{array}$ & $\begin{array}{l}\text { Handing over, washing, } \\
\text { drying, ironing, } \\
\text { administrative activities. }\end{array}$ \\
\hline
\end{tabular}

In the model above, we classified the cost for detergent and softener as a direct cost, whereas indirect cost consisted of 17 types of cost. There were nine activities that occurred in the laundry company that was successfully identified. The Table 1 shows the resource cost driver chosen to allocate indirect cost to each activity that used the resource. The total cost allocated to every activity was then charged to cost object by using the following activity cost driver (Table 2):

Table 2 Activity Cost Driver for Charging Activity Cost to Cost Object

\begin{tabular}{|c|c|}
\hline Activity & Activity Cost Driver \\
\hline $\begin{array}{l}\text { Picking dirty clothes from } \\
\text { customers }\end{array}$ & Frequency of picking dirty clothes from customers \\
\hline Handing over & Number of invoices \\
\hline Washing preparation & Number of kg of clothes \\
\hline Washing & Number of batches for washing \\
\hline Drying & $\begin{array}{l}\text { Number of batches for drying (the same as the } \\
\text { number of batches for washing) }\end{array}$ \\
\hline Packing & Number of invoices \\
\hline $\begin{array}{l}\text { Delivering clean clothes to } \\
\text { customers }\end{array}$ & $\begin{array}{l}\text { Frequency of delivering clean clothes to customers } \\
\text { (the same as the frequency of picking dirty clothes) }\end{array}$ \\
\hline Administration & Number of invoices \\
\hline
\end{tabular}

In the previous research, we have not included environmental impact and cost. Thus, in the present research, we have reinterviewed the same laundry companies like those in the previous research, and also some eco laundry companies to know the differences between the two types of laundry companies. This was done to obtain complete information concerning the environmental impact and cost that would affect the formation of the later model.

\section{Findings from Regular Laundry Business}

From this research, there are some findings which are related to regular laundry companies (not eco laundry companies). They are: 
Kosasih, Yuniawati, Suryaputra, \& Limijaya

Model for Calculating Cost of Laundry Services by Considering Environmental Impacts and Costs

1) They used detergent, which is commonly sold (some are without brands) and which pollutes the environment. For example, the result of the test conducted by Bandung Environmental Management Board (BPLH) (Pikiran Rakyat 2010) showed that it contained some substances which exceeded the required quality standards. It is suggested that before the wastewater is discharged to the river or open drain, it should first be processed so that its contents fit the quality standards. In another research done in Sleman District (Putro), it was known that the majority of the laundry companies did not have a waste management mechanism. This can spur the growth of eceng gondok and water weed, which can make the river shallow and the overflow blocked. Moreover, laundry waste can also disturb fish ecosystem, fertilize eceng gondok and other water plants (it can lower the oxygen in the water so that it can disturb the living organisms in the water), and can be dangerous to human health (Targeted News Service 2014). It is also found out that the product used in both washing and drying activities can cause air pollution through the drain of the dryers (Steinemann, Gallagher, Davis, \& MacGregor, 2013). In general, laundry companies which are categorized as a small business have not possessed wastewater treatment installation (IPAL) due to the high cost. It is suggested that several laundry companies which are closely located should build one together so that the cost can be shared among them. Besides, to reduce environmental impact, laundry companies should make use of eco-friendly detergent, which contains natural active ingredients (http://www.deterjennasional.com/product-list/deterjeneco-green/) or brands which clearly state the ingredients which suit the quality standards.

2) They used plastic material to pack clean clothes in the form of clear plastic, which gives a negative impact on the environment. Based on this research, at present, there is no other material that can substitute the plastic material. In order to make eco-friendly, used clear plastic can be recycled or reused, but this certainly depends much on the consumers.

3) They used plastic bags when handing over or delivering packages to customers. This widely used plastic material is not eco-friendly; it cannot be destroyed in a short time. There is still a way out that can be suggested to the owners of the laundry companies, that is, they can use eco friendly plastic although it will cost more, or they can make use of reusable material such as bags made of cloth or bags made from cassava, which can be destroyed when exposed to water.

4) There are still quite a lot of laundry companies that do not have a business license. At first, they just wanted to try running the business, but then they forgot to apply for the license. It is suggested that the owners of the laundry companies who do not have a business license should soon apply for one so that orderly environment, law, and administration can be reached. The absence of business license causes data collection as a whole cannot be done.

\section{Findings from Eco Laundry Business}

As mentioned before, we also visited eco laundry companies, and the findings are as follows: 
Kosasih, Yuniawati, Suryaputra, \& Limijaya

Model for Calculating Cost of Laundry Services by Considering Environmental Impacts and Costs

1) Eco laundry can be simply defined as the awareness of washing without damaging the environment by making use of technology to save water usage, cleaning effectively with chemical substances which are not dangerous, skin safe, and which maintain the color and fiber of the clothes for longer use. In their implementation, eco laundry companies generally use eco-friendly detergent, that is, water-based detergent which dissolves easily in water so that water will be less used. Wastewater is also safe to be dumped due to the use of eco-friendly detergent. Besides, detergent suppliers have also been certified eco-friendly. However, the price of eco-friendly detergent is certainly higher than regular detergent. Also, eco laundry businesses follow the washing instructions on the label.

2) The selling price is determined by looking at the market price (market-based approach), then they set up a higher selling price than the market price for laundry, which is not eco laundry. They have not calculated the service cost for laundry.

\section{Analysis of Environmental Cost Arising from Laundry Business}

Based on the above discussion, it can be seen that in general, both regular laundry business and eco laundry business have not calculated the cost. Eco laundry business has started to be aware of running their business not only to gain profit but also to keep and maintain the environment in order not to get the negative impact of their business activities. To emphasize more the importance of environment in running a business, businessmen need to identify, classify, and calculate the kinds of environmental cost arising from the business activities, so that the cost can be well managed. Based on the discussion on several groupings of environmental cost in Chapter Two, we used the classification from EPA because we assumed that the classification is complete enough; it consists of 5 groups: conventional, hidden, contingent, relationship and image, and societal costs. We tried to identify environmental costs arising from the laundry business, classifying them, and relate them to the chart of charging cost based on our previous research. The results are as shown in Table 3.

The cost of customers forgone as well as the environmental cost borne by wider society are yet to be included in the costing system as portrayed in Figure 3. The reason for this is because these costs are not incurred yet, or even if they are, it is difficult to detect them, so it is very challenging to measure and assign them to the cost object. Nevertheless, companies should be aware of the existence of these costs and the impact they may have in the future:

1) Cost of customers forgone

To estimate this cost, companies can make customers database that consists of customers' data, including domicile, to collect information on whether the customers with the preference of doing environmental-friendly laundry do live nearby. Companies can also distribute a questionnaire to the neighborhood to ask if they already did some sort of laundry in the business. If not, they should 
explain why; if it is related to an environmental issue, then this can be considered as potential customers forgone.

2) Environmental costs are borne by society

If companies do not manage their wastewater, then the impact it may have can be regarded as environmental cost borne by society, such as the cost of cleaning up the river due to pollution, the cost of medication due to water/ air pollution caused by laundry activities, damaged ecosystem, and the decrease in productivity.

Table 3 Identification, Classification, and Treatment towards Environmental Cost Arising from Laundry Business

\begin{tabular}{|c|c|c|c|c|}
\hline No & Environmental Cost & $\begin{array}{l}\text { Classification } \\
\text { (EPA) }\end{array}$ & $\begin{array}{l}\text { Cost } \\
\text { (in Figure 3) }\end{array}$ & $\begin{array}{l}\text { Allocated to } \\
\text { activity (in } \\
\text { Figure 3) }\end{array}$ \\
\hline 1 & Eco detergent & Conventional & Detergent & Direct cost \\
\hline 2 & Eco-plastic & Conventional & Plastic bags & Packing \\
\hline 3 & $\begin{array}{l}\text {-Cost of finding suppliers, } \\
\text { machines, etc. which are eco- } \\
\text { friendly } \\
\text { - Additional cost because of } \\
\text { using wasteful electric } \\
\text { machines (e.g., cost of } \\
\text { additional electrical power) } \\
\text { - Cost of repairing broken } \\
\text { machines } \\
\text { - Cost arising from a process that } \\
\text { must be repeated due to } \\
\text { broken machines when the } \\
\text { process is in progress }\end{array}$ & Hidden & Administration & Administration \\
\hline 4 & $\begin{array}{l}\text { Government fine for not abiding } \\
\text { the rules }\end{array}$ & Contingent & $\begin{array}{l}\text { Adding the cost } \\
\text { of activities } \\
\text { which cause fine } \\
\text { due to carelessly } \\
\text { disposed waste }\end{array}$ & $\begin{array}{c}\text { Washing } \\
\text { activity } \\
\text { (wastewater), } \\
\text { drying activity } \\
\text { (water/air } \\
\text { pollution) }\end{array}$ \\
\hline 5 & Loss of customers & $\begin{array}{l}\text { Relationship } \\
\text { and image }\end{array}$ & - & - \\
\hline 6 & $\begin{array}{l}\text { The environmental cost is borne } \\
\text { by society }\end{array}$ & Societal & - & - \\
\hline
\end{tabular}

After identifying the environmental costs, the next step is to measure them. Among the availability of methods to measure environmental costs as explained in chapter 2, for environmental costs number 1-3 in Table 3, we recommend using the hedonic pricing method, as it is the most feasible and understandable one compared to other methods. By using this method, environmental costs are calculated implicitly by finding the difference in the price of regular versus eco laundry, which indicates the customer's willingness to pay more to cover environmental costs. Meanwhile, for environmental costs number 4-6 in Table 3, it is suggested to use the contingent valuation method, by using a survey or questionnaire to create assumptions according to hypothetical 
Kosasih, Yuniawati, Suryaputra, \& Limijaya

Model for Calculating Cost of Laundry Services by Considering Environmental Impacts and Costs

behavior. Alternatively, the productivity approach (to estimate the change in the quality of the environment, e.g., its productivity, then to quantify it) or replacement cost method (to estimate the environment restoration cost) can also be used for environmental cost number 6 . For environmental cost number 4 , the amount of sanction and fine imposed can be found by referring to the relevant laws or regulation.

By considering the environmental impact and costs, then the original model will change as follows:

1) Resources

a. Detergent and softener: switched by using environmental-friendly ones. In addition, there will be less detergent usage to adjust it to the capacity, hence reducing water pollution, and the wastewater can be reused and managed better.

b. Electricity: switched to the solar panel.

c. Plastic bags: shifted to using eco-friendly bags to ease the degradation process, or customers may bring their own bags.

d. Washing machine: shifted to the ones with high electricity and water usage efficiency.

e. Dryer: shifted to the ones with high electricity usage efficiency.

f. Iron: shifted to the ones with temperature control.

2) Activity consumption

a. Ironing activity: saving in electricity usage due to the use of irons with temperature control. Ironing is performed when needed only.

b. Picking dirty clothes and delivering clean clothes activity: less frequency by optimizing this activity through careful delivery scheduling.

c. Washing activity: saving due to the management's policy to wash according to the washing machine's capacity.

d. Drying activity: saving due to sun-drying the laundry instead of using the dryer machine, if the weather is supportive.

Thus, the equation is as follows:

$Y=Z 1+a 1 X_{1}+b 1 X_{2}+c 1 X_{3}+d 1 X_{4}$

Where:

$\mathbf{Y}=$ cost per kg or per customer or per invoice

$\mathbf{Z 1}$ = direct cost: eco-friendly detergent and softener usage

a1 = activity cost pool rate with the number of an invoice as the cost driver

$\mathbf{X}_{\mathbf{1}}=$ number of invoice

b1 = activity cost pool rate with a number of $\mathrm{kg}$ as the cost driver

$\mathbf{X}_{\mathbf{2}}=$ number of $\mathrm{kg}$

c1 = activity cost pool rate with picking dirty clothes and delivering clean clothes

frequency as the cost driver 
Kosasih, Yuniawati, Suryaputra, \& Limijaya

Model for Calculating Cost of Laundry Services by Considering Environmental Impacts and Costs

$\mathbf{X}_{\mathbf{3}}=$ frequency of picking dirty clothes and delivering clean clothes

d1 = activity cost pool rate with the number of the batch for washing/ drying as the cost driver

$\mathbf{X}_{4}=$ number of the batch for washing/ drying

The changes in the model, as described above, are an ideal situation, i.e., the prevention steps to environmental damage are performed early. If the ideal situation cannot be fulfilled, then a new resource will emerge: the cost of waste processing, which consists of the maintenance/ replacement cost or cleaning-up cost for the dryer filter, the cost of constructing a funnel, wastewater cleaning-up cost which is allocated to the waste treatment activity (a new one). This activity relates to waste treatment, especially wastewater resulting from washing activity, so it is expected that the water discharged to the environment will not be harmful. If possible, the wastewater which has been treated can be reused, reducing the water usage, thus its cost. This activity is classified as facility sustaining cost, and will be allocated to the cost object using several $\mathrm{kg}$ as the cost driver.

\section{Analysis of Efforts to Overcome Environmental Impact}

The awareness of environmental issues resulting from running a business, including laundry business, has been increased for the past few years. Businesses are starting to realize the importance of having a sustainable way of doing business. In the laundry sector itself, there have been some efforts performed to reduce the negative impact it may have on the environment, such as using energy-efficient washing machine or dryer, supported by the advancement of technology. However, this kind of approach might be less effective; a more comprehensive and integrated approach is needed, for example, through the government's role in performing its duty as a regulator. The government, through Badan Lingkungan Hidup (BLH - Environmental Agency), has performed some efforts to reduce the negative impact of laundry business on the environment. For instance, in Yogyakarta (Yuda 2013; TribunJogja2013), where every laundry has to have nuisance permit, laundry businesses must use eco-friendly detergent, waste is not allowed to be discharged to Saluran Limbah Kota (city sewer), and every laundry business should have a special treatment to neutralize their waste.

In fact, however, this control and supervision role has not been optimum, partly caused by the lack of personnel and the incompleteness of laundry business database as there are still many who do not have a business license. Thus, the government must increase its supervising role to make sure the designed efforts are put in place, for example through the imposition of sanctions. Moreover, the government should also be stricter in terms of business license and active in socializing pre-treatment to waste, as well as mapping the impact of laundry businesses in every region (Pramesti 2012), so that the necessary monitoring and action can be performed accordingly. Socialization to the laundry business regarding the adverse impact of their activities to the environment may also be conducted, as probably some of them are still not fully aware of this issue. A simple educative approach, such as an explanation of methods that can be used to 
Kosasih, Yuniawati, Suryaputra, \& Limijaya

Model for Calculating Cost of Laundry Services by Considering Environmental Impacts and Costs

treat wastewater, or countermeasures to the damaging impact of the laundry business to the environment by planting eceng gondok (Satriyadi 2014), can be considered.

A proper wastewater treatment plant is also essential in efforts to reduce the adverse impact of laundry business on the environment. An example of a success story comes from the Green Laundry, located in Kampung Jarakosta, Desa Sukadanau, Kecamatan Cikarang Barat, Kabupaten Bekasi, which already has a simple treatment plant, in cooperation with Coca-Cola Amatil through its CSR (https://bisnisukm.com/usahalaundry-ramah-lingkungan-dilengkapi-ipal.html). The technology used is quite simple, and the resulting wastewater can be used for watering the plants. In the future, the wastewater is expected to be utilized for catfish cultivation. By sharing such a success story, it is expected that other laundry businesses will be motivated to do similar efforts.

To sum up, some efforts that can be performed by laundry businesses to countermeasure their negative impact on the environment are (1) to perform the waste treatment and pollution prevention steps accordingly (2) to replace materials with the environmental-friendly ones, e.g., detergent, plastic bags (3) to reduce electricity and water consumption.

\section{Conclusion}

There are some conclusions that can be derived from this research. First, the resulting environmental impact from laundry business activities is, among others: wastewater from detergent, air pollution resulting from drying activity, and the use of plastic bags for packing. Since the majority of laundry businesses are still classified as a small business, some of them neither have the business license nor proper mechanisms to the resultant waste. However, it seems that the awareness of environmental issues is rising by the emergence of eco laundry. Next, it can be concluded that both regular and eco laundry businesses, in general, do not perform a cost of service calculation. With regards to analyzing the environmental costs, we used EPA classification as it is regarded as quite comprehensive, consisting of 5 classifications: conventional, hidden, contingent, relationship and image, and societal costs. We found that some environmental costs arising from laundry business activities are difficult to measure as they are not yet incurred, or even if they have it is hard to detect, so it is challenging to measure and assign them to the cost object. Finally, some methods to calculate environmental costs are suggested.

Limitation of this research is that the model developed by authors is still in the theoretical/ conceptual phase; it is yet to involve quantitative data. Compared to the previous method, there are changes in the equation's constant and coefficient due to considering environmental impact and costs. Meanwhile, there are some implications of this research for the laundry businesses as well as the government. For laundry businesses, they could consider to create a customer's database to know their customers' preferences and to start considering some efforts to alleviate the adverse impact of their activities to the environment, such as: to reduce the usage of dryer by 
switching to solar panel, to substitute detergent and plastic bags with environmentalfriendly ones, to perform simple wastewater treatment, to reduce electricity usage as the main source of laundry activities, and to reduce the water consumption. Whereas for the government, there is a call to perform a more comprehensive and integrated approach to overcome the environmental impact of the laundry businesses, through improving its role as a regulator, for example by applying the rule on business license and stricken sanctions imposed. In addition, the government is also expected to socialize actively and educate laundry businesses on ways or methods to manage their waste.

Some suggestions for further research are, among others, to conduct some tests on water quality by the expert to identify whether laundry business activities lower the water quality, to broaden the scope to other areas as well, to broaden the research object including eco laundry, and to perform environmental costs calculation quantitatively using the appropriate method.

\section{Acknowledgment}

This research has been awarded a grant by The Ministry of Research, Technology and Higher Education of the Republic of Indonesia under the scheme "Hibah Bersaing" for the year 2016.

\section{References}

Asfawi, S., Yuantari, M.G., \& Catur. (2014). Dampak Usaba Laundry Terbadap Tingkat Pencemaran Air (Studi Kasus di Kelurahan Pindrikan Kidul). Thesis, Universitas Dian Nuswantoro, Indonesia.

Carter, W.K., Usry, M.F. \& Hammer, L.H. (2002). Cost Accounting 13 th ed. Thomson Learning. Chea, A. C. (2011). Activity-based costing system in the service sector: A strategic approach for enhancing managerial decision making and competitiveness. International Journal of Business and Management, 6(11), 3. Retrieved from http://vulms.vu.edu.pk/Courses/MGT605/Downloads/ActivityBased $\% 20$ Costing $\% 20$ System $\% 20$ in $\% 20$ the $\% 20$ Service $\% 20$ Sector $\% 20 \mathrm{~A} \% 20$ Strateg ic $\% 20$ Approach $\% 20$ for $\% 20$ Enhancing $\% 20$ Managerial $\% 20$ Decision $\% 20$ Making $\% 2$ 0and $\% 20$ Competitiveness.pdf

Collier, P. M. (2015). Accounting for managers: Interpreting accounting information for decision making. John Wiley \& Sons.

Datar, S.M. \& Rajan, M. V. (2018). Horngren's Cost Accounting: A Managerial Emphasis 16 ${ }^{\text {th }}$ ed. Pearson Education Limited.

Garrison,R.H., Noreen, E.W.,Brewer,P.C. (2015). Managerial Accounting. McGraw-Hill Companies, Inc.

Guan, L,. Don R.H, Maryanne M.M. (2009). Cost Management. South-Western Cengage Learning.

Gunarathne, N., \& Lee, K. H. (2015). Environmental Management Accounting (EMA) for environmental management and organizational change: An eco-control 
approach. Journal of Accounting \&o Organizational Change, 11(3), 362-383. https://doi.org/10.1108/JAOC-10-2013-0078

Hilton, R.W. \& Platt, D.E. (2015). Managerial Accounting: Creating V alue in a Dynamic Business Environment, 10 thed. Global Edition. McGraw Hill.

Jankovic, S., Persic, M. \& Gavranic, T.Z. (2011). Framework for development of environmental management accounting in Croation hospitality industry. Sustainable Tourism: Socio-Cultural, Environmental and Economics Impact, 121-135.

Kaplan, R.S. \& Atkinson, A.A. (1998). Advanced Management Accounting, $3^{\text {rd }}$ ed. Prentice Hall International.

Kosasih, E., Yuniawati, A., Suryaputra, V. \& Limijaya, A. (2017). Model perhitungan harga pokok untuk perusahaan laundry. Jurnal ASET (Akuntansi Riset), 9(2), 1-14. http://dx.doi.org/10.17509/jaset.v9i2.9219

Kreuze, J. G., \& Newell, G. E. (1994). ABC and life-cycle costing for environmental expenditures. Strategic Finance, 75(8), 38. Retrieved from https://search.proquest.com/openview/7509ece09a6b40a0471eb1de055b22ff/1?p q-origsite $=$ gscholar\&cbl $=48426$

Laitala, K., Boks, C., \& Klepp, I. G. (2011). Potential for environmental improvements in laundering. International Journal of Consumer Studies, 35(2), 254-264. https://doi.org/10.1111/j.1470-6431.2010.00968.x

Laitala, K., Klepp, I. G., \& Boks, C. (2012). Changing laundry habits in Norway. International Journal of Consumer Studies, 36(2), 228-237. https://doi.org/10.1111/i.14706431.2011.01081.x

Langfield-Smith, Thorne \&Hilton. (2009). Management Accounting - Information for Creating and Managing Value, 5th ed. McGraw Hill Australia Pty ltd.

Mir, D. F., \& Feitelson, E. (2007). Factors affecting environmental behavior in microenterprises: Laundry and motor vehicle repair firms in Jerusalem. International Small Business Journal, 25(4), 383-415. https://doi.org/10.1177/0266242607078583

Ngwakwe, C.C. (2009). Justifying environmental cost allocation in a multiple product firm: A case study. Managing Global Transitions, 7(4), 403-420. Retrieved from http://www.fm.upr.si/zalozba/ISSN/1581-6311/7-4.pdf\#page=77

Onat, O.K., Anitsal, I., \& Anitsal, M.M. (2014). Activity based costing in services industry: A conceptual framework for entrepreneurs. The Entrepreneurial Executive, 19, 149-167. Retrieved from https://www.abacademies.org/articles/eevol1912014.pdf\#page $=159$

Putro, R.A. (2014). Potensi Dampak Usaha Laundry Kilo anter hadap Lingkungan Hidup terkait Limbah dan Pemanfaatan Air Tanah di Kecamatan Depok. Thesis, Universitas Gadjah Mada, Indonesia. Retrieved from http:/ / etd.repository.ugm.ac.id/index.php?act=view\&buku $\mathrm{id}=73662 \& \mathrm{mod}=$ penel itian detail\&sub=PenelitianDetail\&typ $=$ html

Rimer, A.E. (2000). Identifying, reducing, and controlling environmental costs. Plant Engineering, 54(3), p. 114.

Rogers, G. \& Kristof, J. (2003). Reducing operational and product costs through environmental accounting. Environmental Quality Management, Spring 2003, 12(3), 17 42. https://doi.org/10.1002/tqem.10071

Satriyadi. (2014). Perubahan Lingkungan akibat Pencemaran Limbah Cair Industri Kecil Laundry dan Cara Pencegahannya. Thesis, Universitas Sumatera Utara, Indonesia.

Steinemann, A. C., Gallagher, L. G., Davis, A. L., \& MacGregor, I. C. (2013). Chemical emissions from residential dryer vents during use of fragranced laundry products. Air Quality, Atmosphere \& Health, 6(1), 151-156. https://doi.org/10.1007/s11869-011-0156-1 
Yuda, I.M.E. (2013). Peran Badan Lingkungan Hidup dalam Pengawasan Kegiatan Usaha Laundry sebagai Upaya Pengendalian Pencemaran Lingkungan di Kota Yogyakarta. Thesis, Unversitas Atma Jaya Yogyakarta, Indonesia.

\section{Regulation:}

Sigma Guidelines. (2003). The Sigma Guidelines-Toolkit, Sustainability Accounting Guide. London.

Article in Website:

Pramesti, O.L. (2012). Jasa Laundry Picu Pencemaran Limbah B3 http:/ / nationalgeograpbic.co.id/ berita/2012/04/jasa-laundry-picu-pencemaran-limbah-b3 http://swa.co.id/business-strategy/marketing/hebat-omset-bisnis-clean-laundry-capai-rp$\underline{60 \text {-triliun }}$

http://www.beritasatu.com/ekonomi-karier/170934-industri-laundry-di-indonesiaberkembang-pesat-tenaga-kurang.html\&http://www.pikiranrakyat.com/ekonomi/2014/03/12/273506/usaha-laundry-di-indonesiaberkembang-pesat

http://www.deterjennasional.com/product-list/deterjen-eco-green/ http://www.pewangilaundry.co.id/pengertian-usaha-laundry.html https://bisnisukm.com/usaha-laundry-ramah-lingkungan-dilengkapi-ipal.html http://www.ecosystemvaluation.org/

\section{Article in Daily News:}

Esa. (2013). Limbah Laundry Beresiko Cemari Air Tanah. Tribun Yogya.

Pikiran Rakyat. (2010). Pengusaha Laundry Diminta Gunakan Deterjen Ramah Lingkungan, 27 Oct 2010.

Targeted News Service. (2014). Chemicals in Laundry Water Polluting US Waterways. The Guardian. (2014). How to Drive Household's Laundry Behavior Towards a More Sustainable One. Oct 2014 